\title{
The analysis of the causes of the collapse of two timber sheds during the construction
}

\author{
Józef Szczotka ${ }^{1, *}$ \\ ${ }^{1}$ F.U.I Józef Szczotka,43-426 Gumna, Miodowa 31, Poland
}

\begin{abstract}
The paper describes collapses of two timber sheds located in Cieszyn and Zebrzydowice, Poland. The collapses took place during the construction process. The structures of the sheds are described, the construction works are analysed, the causes of the collapses are determined and the recommendations and technical solutions regarding their repair are presented.
\end{abstract}

\section{Introduction}

In order to gain covered space, investors often build timber sheds. Timber as construction material has been very popular recently due to low costs of timber constructions. The availability of timber in Poland is good and its transport is easy. Timber structures are erected very fast and low temperature is not an issue [1]. According to the present legislation in Poland, sheds do not require building permits or registration in accordance with the art. 29. par. 1, point $2 \mathrm{c}$ regarding the art. 30 par. 1 point 1 of the Polish Construction Law. The covered surface of a shed may reach up to $50 \mathrm{sq}$. $\mathrm{m}$ and the number of sheds per 500 sq. $\mathrm{m}$ cannot exceed one. Sheds have multiple purposes: recreation, storage, space for cars, etc. Another attractive feature of sheds is the fact that their surface is local tax-free. For the sake of savings most investors do not prepare any construction designs of sheds or supervise their erection employing licenced construction experts. Due to the simplicity of their construction process, sheds are frequently made by pseudo-construction firms which prepare the material, assess the static system as well the kinds of joints. In many cases sheds are constructed wrongly from the beginning of the process and may cause potential danger for their users.

\section{The description of the sheds}

Sheds are detached one-storey buildings. The foundations in both cases were made of foundation blocks under every post. The foundations were monolithic and reached the ground freezing depth of $1 \mathrm{~m}$. The joints between the posts and the blocks were made with metal anchors fixed with nails. The design of the roofing was made as if it were collar beam. In both cases there was no construction or calculation record of the parts of the sheds. The sizes of the parts as well as the manner of their connection were accidental and unsupported by any calculations. The structure of both sheds was stiffened with struts between the posts and

\footnotetext{
*Corresponding author: j.szczotka@outlook.com
} 
the wall plates only longitudinally and not transversally. The anchors connecting the foundations with the posts were small and should not have been used in such structures. Although the roofing material was different (the shed in Cieszyn was covered with concrete rooftiles and the one in Zebrzydowice with sheet metal), both contractors used the same sizes of the parts. The diagrams of the sheds are shown in Fig. 1.
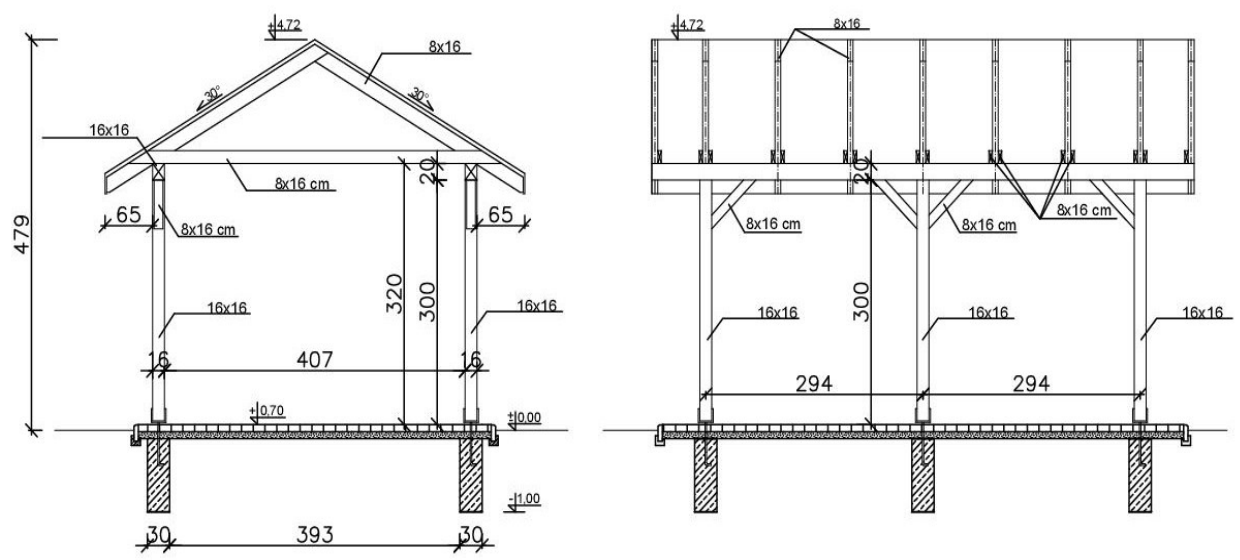

Fig. 1. The diagrams of the sheds.

\section{The construction works till the collapse}

One of the sheds was designed for leisure purposes and the other as a garage for an ambulance. The construction works of the timber sheds commenced after the investor and contractor had agreed on the basic dimensions (without any construction design). The contractor made the monolithic foundation blocks of $20 \mathrm{~cm}$ in diameter where the metal anchors $16 \times 12 \times 6 \mathrm{~cm}$ were fixed. The load bearing structure consisted of the following parts made of spruce:

- Rafters 8 x $16 \mathrm{~cm}$.

- Collar beams $8 \times 16 \mathrm{~cm}$.

- Posts $16 \times 16 \mathrm{~cm}$.

- Struts $16 \times 16 \mathrm{~cm}$.

- Purlins $16 \times 16 \mathrm{~cm}$.

Struts were made longitudinally against the posts. The posts were not stiffened transversally. The roofing of one shed was made of concrete rooftiles and the other of sheet metal on full timber board. The roof drainage was made of PVC gutters and pipes. The difference in erection of the two sheds was the fact that in one of them there was no temporary transversal stiffening or struts and in the other one there was certain construction protection during the process of construction. Professional technical evaluation done after the collapse revealed that the shed covered by concrete tiles collapsed during the construction and the other one after the construction was finished.

\section{The description of the collapse}

The shed in Cieszyn collapsed on $4^{\text {th }}$ August 2015 in the afternoon. The whole structure leaned in transversal direction which was caused by the loss of balance of the posts. The fence of the plot 19/8 and a few trees were also damaged by the falling shed (Fig. 2). 


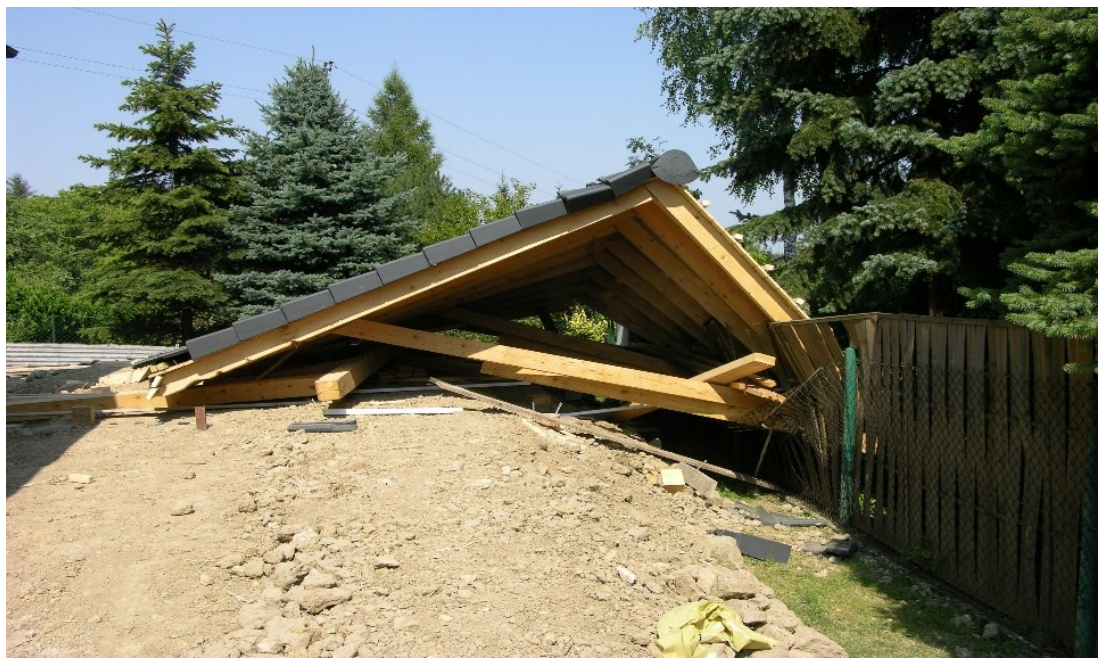

Fig. 2. The shed in Cieszyn after the collapse.

The collapse took place during the construction works and caused injuries of three workers who were working on the roof. Two of them fell off the roof from the height of $4 \mathrm{~m}$.

The other shed in Zebrzydowice near Cieszyn collapsed on $5^{\text {th }}$ August 2016. The whole structure leaned in transversal direction which was caused by the loss of balance of the posts. The collapsed shed is shown in Fig. 3.

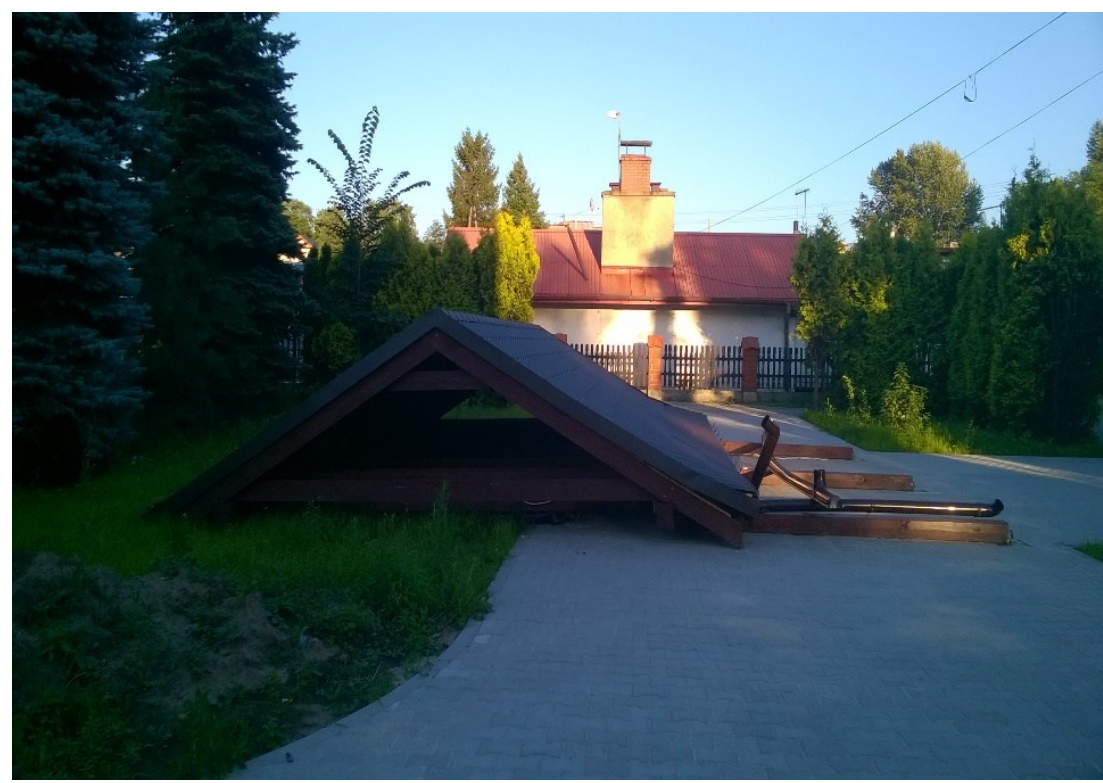

Fig. 3. The shed in Zebrzydowice after the collapse.

During the construction process the contractor used temporary transversal stiffening by struts which were taken off after finishing the construction and that was the moment the collapse took place. None of the workers was injured but because the shed was built in a busy town centre, the collapse caused disturbance in the traffic. 


\section{The analysis of the causes of the collapse}

There were numerous causes of the collapse of the shed in Cieszyn. During the construction process the correct sequence of the works was not observed. The construction of the cementtile roofing had commenced before finishing the structural works and resulted in errors such as the lack of connectors between the posts and foundation anchors (Fig. 4) and the lack of connectors of the collar beams.

During the construction works there was no temporary protection in the form of struts. Another cause of the collapse was the lack of transversal stiffening and bad quality of joining the construction parts such as short nail connections between the rafters and the wall plate (Fig. 5) or too small nails between the rafters ends or even their absence (Fig. 4).

The direct cause of the collapse was the cumulation of the abovementioned factors which resulted in creating torsional stress in the posts and in the end the loss of balance of the shed (Fig. 2).

When the workers started doing the concrete-tile roofing, the collapse took place when barely half of the roof surface had been covered.

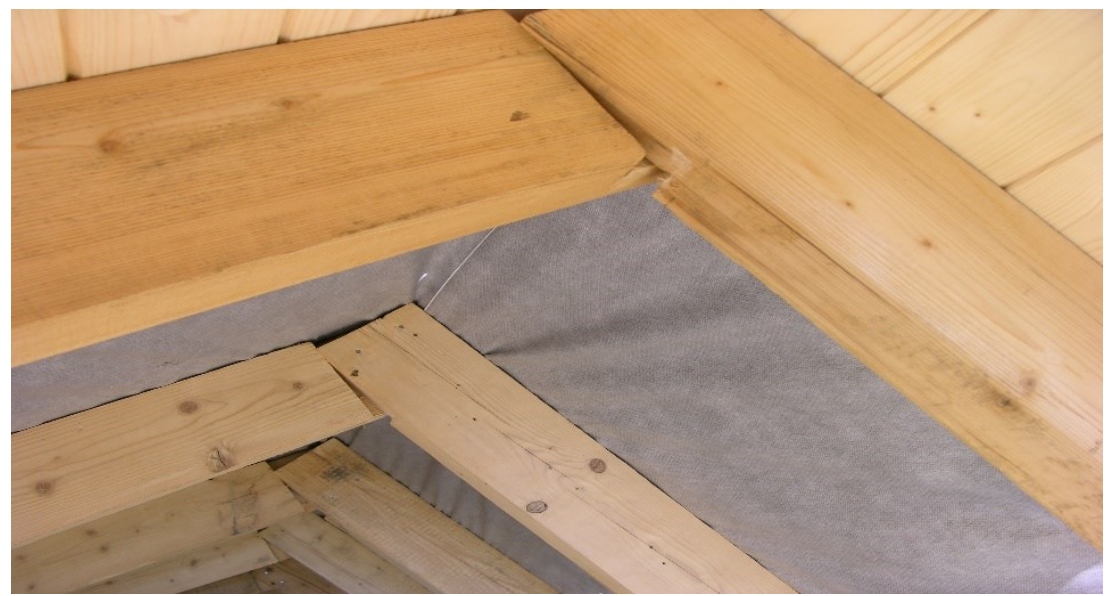

Fig. 4. The rafter - to - rafter connection - not enough or no nails.

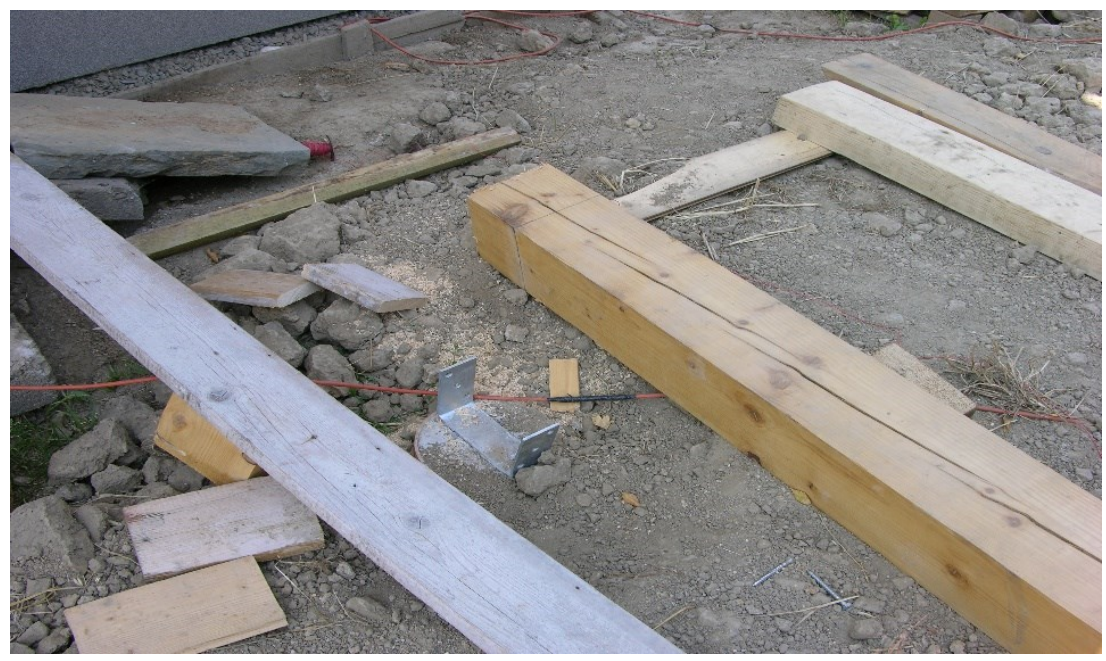

Fig. 5. The post - foundation block connection - no screws in the connection. 
There were also numerous causes of the building collapse of the shed in Zebrzydowice near Cieszyn:

- The lack of transversal stiffening of the shed structure.

- Bad manner of joining the construction parts (short connections between the posts and the wall plate).

- No joining brackets in the post - wall plate connections.

- Badly calculated post - longitudinal strut - wall plate connections.

- Poorly chosen anchors for the post - foundation block connections (Fig. 6).

The collapse took place when the workers took off the struts which had been fixed temporarily for the duration of the construction process. The cumulation of the abovementioned factors resulted in creating torsional stress in the posts and in the end the loss of balance of the shed.

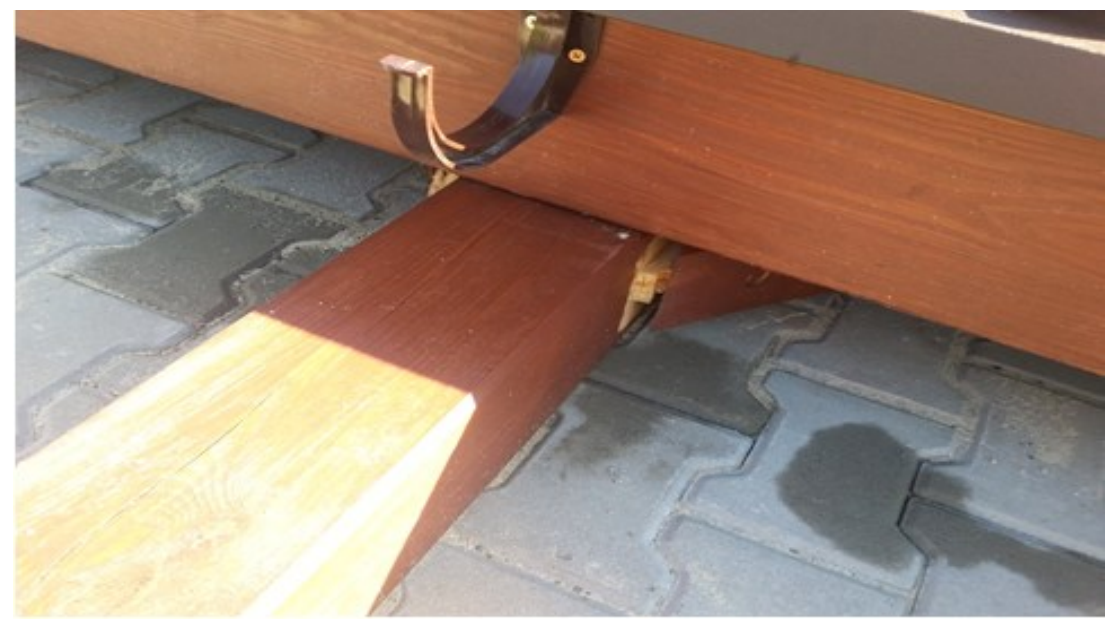

Fig. 6. The lack of screws in the post - foundation block connection.

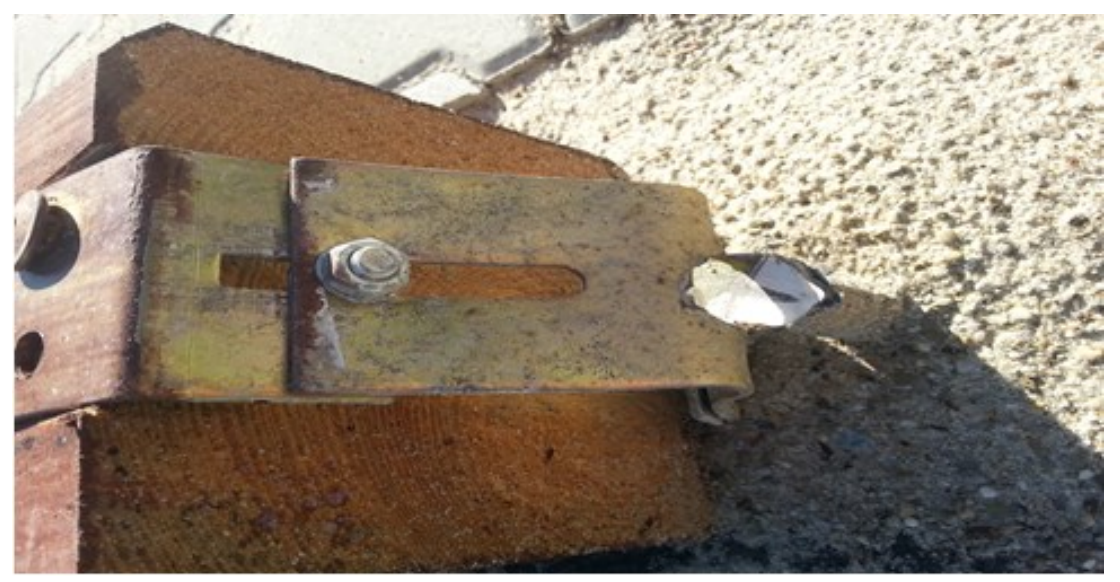

Fig. 7. The post - strut - wall plate connection. 


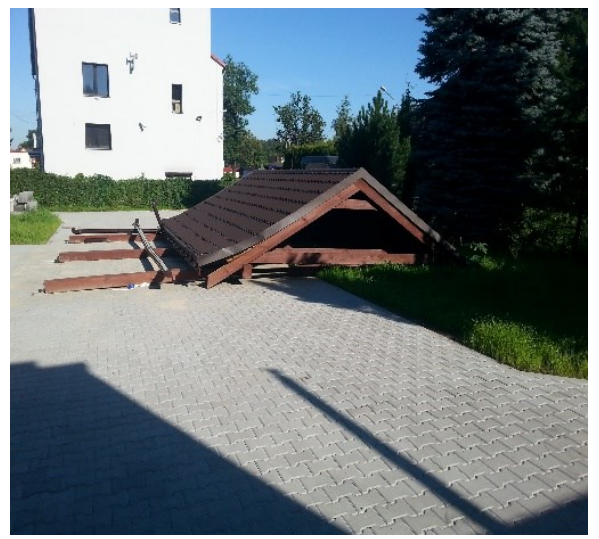

Fig. 8. The shed in Zebrzydowice after the collapse.

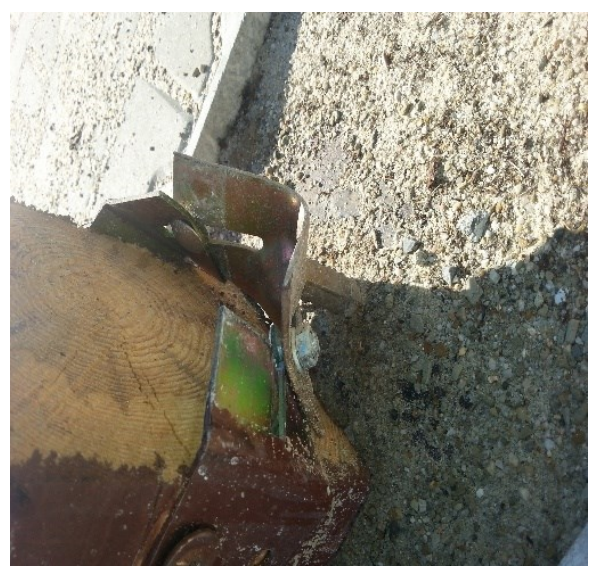

Fig. 10. The column - foundation block connection in Zebrzydowice.

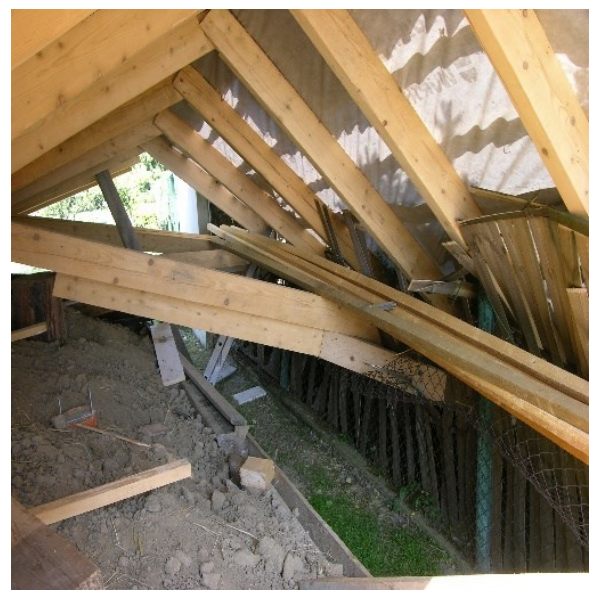

Fig. 12. The shed in Cieszyn after the collapse.

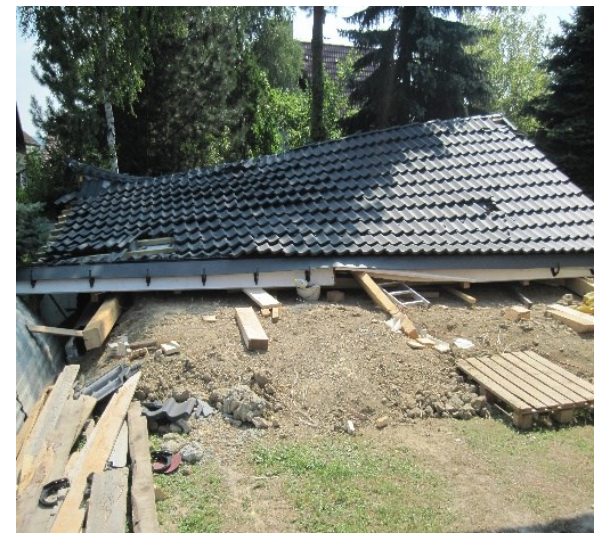

Fig. 9. The shed in Cieszyn after the collapse.

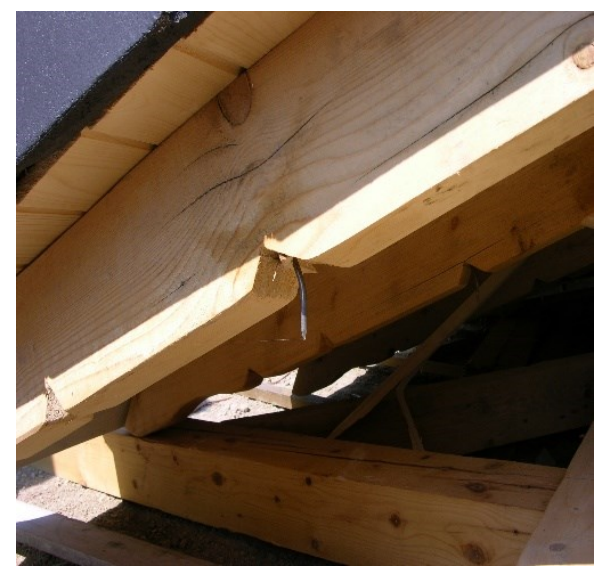

Fig. 11. The rafter - wall plate connection in Cieszyn.

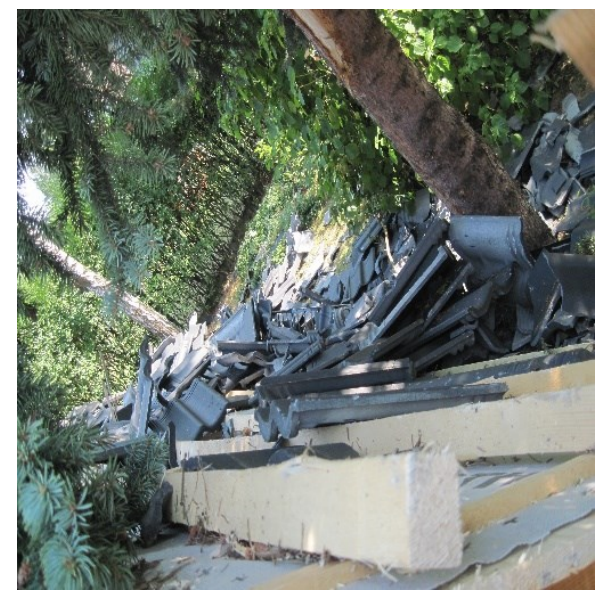

Fig. 13. The damage after the collapse in Cieszyn. 


\section{Conclusion and repair solutions}

In both cases the investors put their trust in the contractors who were designers, construction supervisors and builders at the same time. Although those structures are not complex, both sheds collapsed. The negligence in both cases was very similar and the most important mistakes were:

- The lack of transversal stiffening of the sheds.

- Bad steel anchor - post connections

- Inappropriate connections of the structure parts.

The sheds were not made according to good construction practice or construction norms. The collapse of both structures was the effect of creating torsion stress in the posts and in the end the loss of balance.

The contractor did not follow basic safety rules during the construction process and did not use temporary struts for the duration of the construction works which led to the workers' injuries and substantial loss. The "firm" probably wanted to save money and time compromising their workers' safety.

To sum up, the collapses were the result of the construction mistakes and the lack of the design documentation. In order to avoid such incidents in the future, it would be advisable to reflect on change of the present construction law. Such construction works should be supervised by experts with suitable experience to minimise potential danger. One should also bear in mind that there are a lot of similar structures being built at present.

Having analysed the collapses, technical recommendations were issued in order to finish the construction works safely.

The recommendations regarding the shed in Cieszyn (used for leisure purposes) were followed by [2]:

- Clearing the building site and reuse of some of the material

- Using the SPAX type screws for the connections of the structure parts and designing a transversal stiffening of the shed.

- Making the transversal stiffening of the shed and adding struts as well as transversal beams to the wall plates to form a frame.

- Placing additional beams $16 \times 16 \mathrm{~cm}$ under the posts which stiffened the post - foundation connections.

- Using metal brackets to support the timber parts.

- Preparing a description of the construction works. 


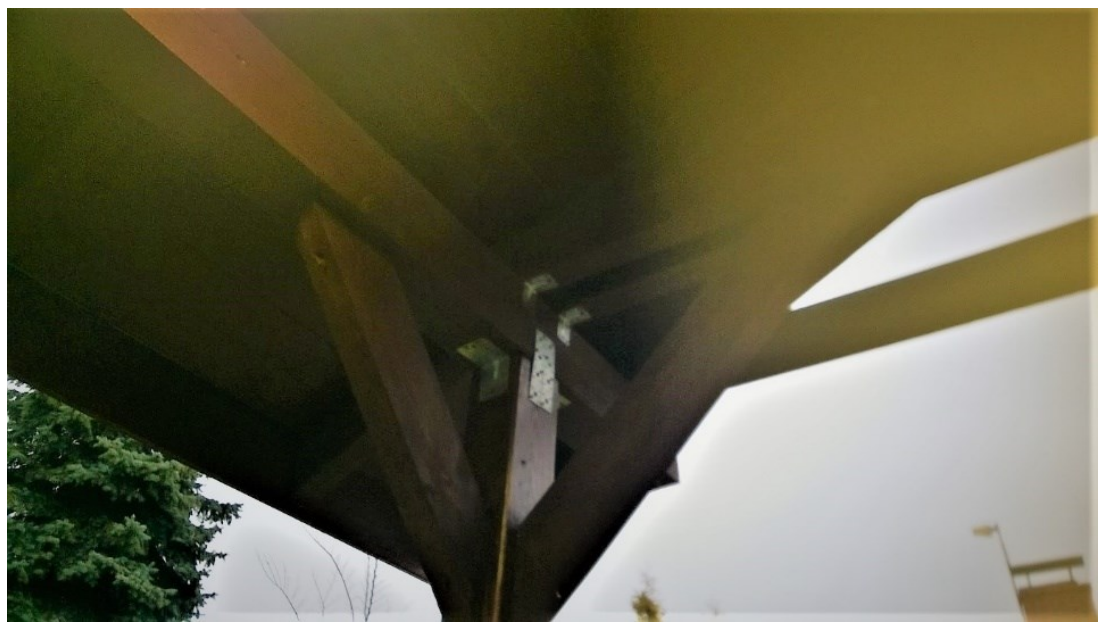

Fig. 14. The column - strut - wall plate connection.

The recommendations regarding the shed in Zebrzydowice (used as a garage for an ambulance) were followed by [3]:

- Clearing the building site and reuse of some of the material

- Using the SPAX type screws for the connections of the structure parts and designing a transversal stiffening of the shed.

- Making the transversal stiffening of the shed and adding struts as well as transversal beams to the wall plates to form a frame.

- Using metal brackets to support the timber parts.

- Preparing a description of the construction works.

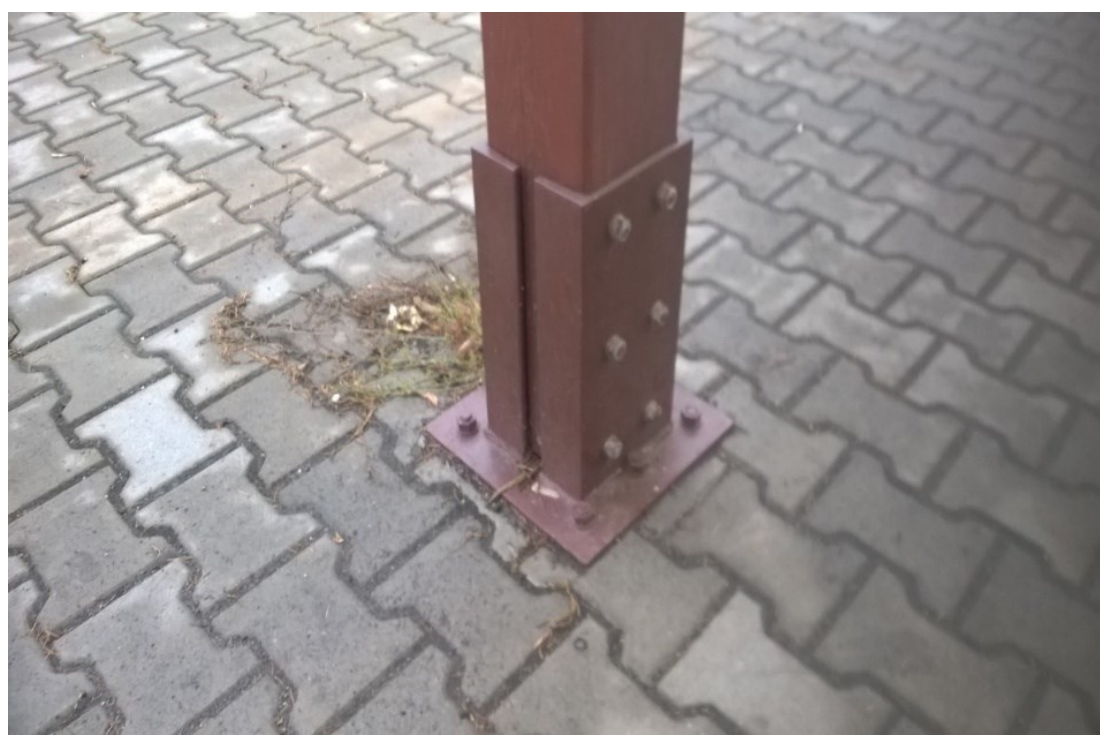

Fig. 15. The post - foundation connection. 


\section{References}

1. Z. Mielczarek, Budownictwo drewniane (Arkady, Warszawa, 1997)

2. J. Szczotka, Ekspertyza techniczna dotyczaca stanu technicznego zawalonej wiaty na skutek katastrofy budowlanej położonej w Cieszynie, zgodnie z Postanowieniem PINB (Cieszyn, 2015)

3. J. Szczotka, Ekspertyza techniczna dotyczaca stanu technicznego zawalonej wiaty na skutek katastrofy budowlanej położonej w Zebrzydowicach koto Cieszyna, zgodnie z Postanowieniem PINB (Cieszyn, 2016) 